\title{
Unveiling the Structure Sensitivity for Direct Conversion of Syngas to C2-Oxygenates with a Multicomponent-Promoted Rh Catalyst
}

\author{
Xiaohui Sun ${ }^{1} \cdot$ Harrie Jansma ${ }^{1} \cdot$ Toshihito Miyama $^{2} \cdot$ Rasika Dasanayake Sanjeewa Aluthge ${ }^{2} \cdot$ Kenichi Shinmei $^{2}$. \\ Noritoshi Yagihashi ${ }^{2} \cdot$ Haruka Nishiyama $^{2} \cdot$ Dmitrii Osadchii $^{1} \cdot$ Bart van der Linden $^{1} \cdot$ Michiel Makkee $^{1}$
}

Received: 29 August 2019 / Accepted: 21 October 2019 / Published online: 6 November 2019

(c) The Author(s) 2019

\begin{abstract}
$\mathrm{Mn}$ and $\mathrm{Li}$ promoted $\mathrm{Rh}$ catalysts supported on $\mathrm{SiO}_{2}$ with a thin $\mathrm{TiO}_{2}$ layer were synthesized by stepwise incipient wetness impregnation approach. The thin $\mathrm{TiO}_{2}$ layer on the surface of $\mathrm{SiO}_{2}$ was proved to stabilize those small $\mathrm{Rh}$ nanoparticles and hinder their agglomeration. The reducibility of $\mathrm{Rh}$ on these catalysts depends on $\mathrm{Rh}$ particle size as well as the position of manganese oxide, and large $\mathrm{Rh}$ nanoparticles with $\mathrm{MnO}$ on $\mathrm{Rh}$ nanoparticles can be only reduced at an elevated temperature. Catalyst with large Rh particles exhibits a higher $\mathrm{CO}$ conversion and higher products selectivity towards long chain hydrocarbons and $\mathrm{C} 2$-oxygenates at the expense of decreasing methane formation than a similar catalyst with smaller $\mathrm{Rh}$ particles. This was attributed to the synergistic effect of $\mathrm{Mn}$ and $\mathrm{Li}$ promotion and molar ratio between $\mathrm{Rh}^{0}$ and $\mathrm{Rh}^{\delta+}$ sites on the surface of $\mathrm{Rh}$ nanoparticles. Moreover, $\mathrm{Rh}$ nanoparticles on $\mathrm{MnO}$ are proved to be more efficient in promoting hydrogenation of acetaldehyde to ethanol than its counterpart with $\mathrm{MnO}$ on $\mathrm{Rh}$ nanoparticles. Finally, in order to target high C2-oxygenates selectivity, low reaction temperature together with a low $\mathrm{H}_{2} / \mathrm{CO}$ ratio in the feed is recommended.
\end{abstract}

\section{Graphic Abstract}

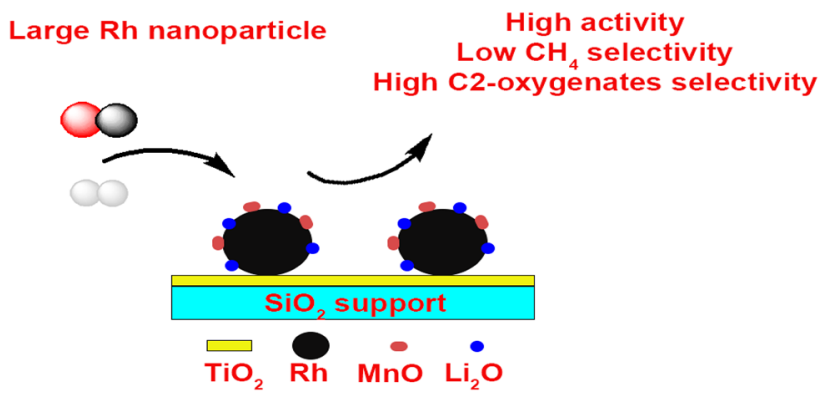

Keywords Ethanol $\cdot$ Acetaldehyde $\cdot \mathrm{Rh} \cdot \mathrm{Mn} \cdot$ Particle size

Electronic supplementary material The online version of this article (https://doi.org/10.1007/s10562-019-03016-x) contains supplementary material, which is available to authorized users.

\section{Xiaohui Sun}

Michiel Makkee M.Makkee@tudelft.nl

1 Catalysis Engineering, Department of Chemical Engineering, Delft University of Technology, Van der Maasweg 9, 2629 HZ Delft, The Netherlands

2 Clean Technology \& Advanced Materials Institute R\&D Center, SEKISUI CHEMICAL CO., LTD., 32, Wadai, Tsukubashi, Ibaraki 300-4292, Japan

\section{Introduction}

The synthesis of renewable fuels such as ethanol has received extensive attention in recent years for its application both as a fuel additive and an energy carrier [1-3]. Nowadays, ethanol is produced mainly by fermentation of biomass-derived sugars [4]. Catalytic conversion of syngas (mixture of $\mathrm{H}_{2}$ and $\mathrm{CO}$ obtained from natural gas, coal or biomass) to oxygenated compounds (ethanol, acetaldehyde and acetic acid), followed by a subsequent hydrogenation of acetaldehyde and acetic acid provides an alternative route 
to produce ethanol at large scales. Several catalytic systems, including rhodium- and/or molybdenum sulfide-based catalysts, and modified Fischer-Tropsch and/or methanol synthesis catalysts have been studied for this purpose [5-8]. Slow kinetics and poor oxygenates selectivity in this process remain, however, the major obstacles. Hence, exploring catalysts with new structure and compositions for $\mathrm{C} 2$-oxygenates synthesis with high activities and oxygenated compounds selectivity still remains a big challenge.

Several transition metals in Group VIII of the Periodic Table have been investigated in $\mathrm{CO}$ hydrogenation, and products were found to clearly depend on the property of metals. Metals (e.g. Ir and Pd) that hardly dissociate CO, favor methanol production $[9,10]$, while cobalt and iron preferably produce long chain hydrocarbons owning to their high capability in CO dissociation [11-14]. Importantly, rhodium, that is located at an intermediate position in the periodic table, and possesses a unique $\mathrm{CO}$ adsorption behavior, has been proved highly efficient in the synthesis of C2-oxygenated compounds from CO hydrogenation [15-17]. Generally stating, $\mathrm{CO}$ hydrogenation to $\mathrm{C} 2$-oxygenates occurs on the surface of rhodium particles. Therefore, the number of active sites, namely the activity is a function of rhodium dispersion [15]. In order to achieve an uniform rhodium distribution, the intrinsic feature of supports and catalyst preparation conditions are supposed to be considered during a catalyst design [18-20]. For instance, silica with large surface area favors the dispersion of rhodium precursors. However, during a follow-up high-temperature thermal treatment, rhodium oxides nanoparticles suffer severe agglomeration owning to a weak rhodium-silica interaction [21]. $\mathrm{TiO}_{2}$ with a strong interaction strengthens the stability of rhodium nanoparticles, while the low surface area leads to a poor metal dispersion [22-24]. Thus, a rational design strategy that can optimize the particle distribution and stability of supported rhodium nanoparticles is highly attractive.

Previous studies showed that supports play an essential role in the catalytic activity and products distribution for rhodium catalysts [25-28]. For example, a $2 \mathrm{wt} \% \mathrm{Rh} / \mathrm{TiO}_{2}$ showed a $\mathrm{CO}$ conversion 8 times as high as the $\mathrm{SiO}_{2}$ supported $\mathrm{Rh}$ catalyst together with an improved $\mathrm{C} 2$-oxygenates selectivity [27]. However, $\mathrm{TiO}_{2}$ supported $\mathrm{Rh}$ catalysts without promotors still primarily produce methane with low C2-oxygenates yield [25-27]. In this sense, a variety of promotors (e.g. La, Mn, Fe, Li, etc.) have been investigated in order to improve $\mathrm{C} 2$-oxygenates selectivity by inhibiting the production of methane [26-31]. For instance, adding small amount of $\mathrm{Fe}$ and/or $\mathrm{Mn}$ into a $\mathrm{Rh} / \mathrm{TiO}_{2}$ catalyst was proven to largely promote the production of ethanol and acetaldehyde at the expense of $\mathrm{CH}_{4}$ selectivity [27, 28]. Owning to the significant promotion effect, the structure and function of $\mathrm{Mn}$ in Rh-based catalysts have been widely studied, and $\mathrm{MnO}$ in close contact with $\mathrm{Rh}$ nanoparticles is in general considered to be the active phase of the promoter [32-36]. The promotion functions of Mn consist of (i) increasing $\mathrm{Rh}$ dispersion; [15, 35] (ii) stabilizing partially oxidized Rh sites for $\mathrm{CO}$ insertion; [33, 37] and (iii) generating interfacial sites between $\mathrm{Rh}$ and $\mathrm{MnO}$ to accelerate $\mathrm{CO}$ dissociation $[32,36]$. Hence, a correlation between $\mathrm{MnO}$ distribution and $\mathrm{C} 2$-oxygenates selectivity would exist in the Mn-promoted Rh catalyst. Normally, co-impregnation is the most popular strategy to prepare bimetallic catalysts [26]. However, the random deposition of $\mathrm{Mn}$ on the catalyst surface largely hinders the evaluation of distribution-promotion relations. In this sense, stepwise impregnation approach would be an alternative to accurately design multicomponent catalyst $[32$, 38].

In this study, to further investigate the relationship between the distribution and promotion functions of $\mathrm{Mn}$ in multicomponent-promoted $\mathrm{Rh}$ catalysts, a series of $\mathrm{Rh}$ based catalysts were prepared by supporting $\mathrm{Rh}, \mathrm{Mn}$, and $\mathrm{Li}$ on a high-surface-area $\mathrm{SiO}_{2}$ support with a thin layer of $\mathrm{TiO}_{2}$ on the silica surface. The addition of $\mathrm{Li}$ in this study is attributed to the fact that $\mathrm{Li}$ was reported to some extent to inhibit methane formation and boost $\mathrm{C} 2$-oxygenates selectivity [39-41]. Catalyst synthesis is composed of several steps: (i) depositing a thin layer of $\mathrm{TiO}_{2}$ on $\mathrm{SiO}_{2}$; (ii) introducing $\mathrm{Mn}$ on $\mathrm{Rh}$ or other way around by stepwise incipientwetness-impregnation (IWI) on the prepared $\mathrm{TiO}_{2} / \mathrm{SiO}_{2}$; (iii) impregnating Li by a further IWI. With this strategy, we demonstrate that the thin $\mathrm{TiO}_{2}$ layer on the surface of $\mathrm{SiO}_{2}$ plays a crucial role in stabilizing $\mathrm{Rh}$ nanoparticles in right dispersion. Furthermore, $\mathrm{Rh}$ on $\mathrm{MnO}$ is more efficient in promoting the hydrogenation of acetaldehyde to ethanol compared to its counterpart with $\mathrm{MnO}$ on $\mathrm{Rh}$. Finally, the catalytic performance of the multicomponent Rh-based catalyst also depends on $\mathrm{Rh}$ particle size, and catalyst with a larger $\mathrm{Rh}$ nanoparticle size exhibits a higher activity and C2-oxygenates selectivity, but lower methane selectivity than its counterpart with smaller Rh nanoparticles. This approach will provide new insight for the rational design of highly active and selective $\mathrm{Rh}$ based catalysts for C2-oxygenates production.

\section{Experimental Section}

\subsection{Materials}

Dihydroxybis(ammonium lactato)titanium(IV) $\left(\mathrm{C}_{6} \mathrm{H}_{18} \mathrm{~N}_{2} \mathrm{O}_{8} \mathrm{Ti}, 50 \% \mathrm{w} / \mathrm{w}\right.$ aq. soln $)$ was purchased from Alfa Aesar, rhodium(III) chloride hydrate $\left(\mathrm{RhCl}_{3} \cdot \mathrm{xH}_{2} \mathrm{O}, 40 \mathrm{wt} \%\right.$ $\mathrm{Rh})$ was purchased from Tanaka Kikinzoku Kogyo KK, manganese(II) chloride tetrahydrate $\left(\mathrm{MnCl}_{2} \cdot 4 \mathrm{H}_{2} \mathrm{O},>99.9 \%\right)$; lithium chloride monohydrate $\left(\mathrm{LiCl} \cdot \mathrm{H}_{2} \mathrm{O},>99.9 \%\right)$ and citric acid $\left(\mathrm{C}_{6} \mathrm{H}_{8} \mathrm{O}_{7},>98 \%\right)$ were purchased from Wako Pure 
Chemical Industries, Ltd. All the chemicals were used without further purification. $\mathrm{SiO}_{2}$ with an average pore size of $6 \mathrm{~nm}$ was provided by Fuji Silysia Chemical, Ltd.

\subsection{Catalyst Synthesis}

$\mathrm{SiO}_{2}$ support was washed with nitric acid (10 wt $\%$ ) overnight, followed by washing with deionized water until the $\mathrm{pH}$ reaches neutral. The powder was further dried in air at $383 \mathrm{~K}$ overnight, followed by calcination at $673 \mathrm{~K}$ for $4.5 \mathrm{~h}$, with a ramping rate of $4 \mathrm{~K} / \mathrm{min}$.

$\mathrm{Ti} / \mathrm{SiO}_{2}-673$ was prepared by IWI of $2 \mathrm{~g} \mathrm{SiO}_{2}$ with a aqueous mixture of $0.098 \mathrm{~g} \mathrm{C}_{6} \mathrm{H}_{18} \mathrm{~N}_{2} \mathrm{O}_{8} \mathrm{Ti}$ and $1.414 \mathrm{~g}$ deionized water. The impregnated sample was kept in a desiccator at room temperature for $0.5 \mathrm{~h}$, dried in an oven at $383 \mathrm{~K}$ for $3 \mathrm{~h}$, and further heated to $673 \mathrm{~K}$ for $4.5 \mathrm{~h}$ in stagnant air.

$2 \mathrm{~g} \mathrm{Ti} / \mathrm{SiO}_{2}$ was impregnated with a aqueous mixture of $0.2188 \mathrm{~g} \mathrm{RhCl}_{3} \cdot \mathrm{xH}_{2} \mathrm{O}, 0.1064 \mathrm{~g} \mathrm{C}_{6} \mathrm{H}_{8} \mathrm{O}_{7}$ and $1.164 \mathrm{~g}$ deionized water, dried at $383 \mathrm{~K}$ for $3 \mathrm{~h}$, and calcined at $673 \mathrm{~K}$ for $4.5 \mathrm{~h}$ in stagnant air. The sample was denoted as $\mathrm{Rh} / \mathrm{Ti} / \mathrm{SiO}_{2}-673$.

$2 \mathrm{~g} \mathrm{Rh} / \mathrm{Ti} / \mathrm{SiO}_{2}-673$ was impregnated with a aqueous mixture of $0.0865 \mathrm{~g} \mathrm{MnCl}_{2} \cdot 4 \mathrm{H}_{2} \mathrm{O}, 0.112 \mathrm{~g} \mathrm{C}_{6} \mathrm{H}_{8} \mathrm{O}_{7}$ and $1.22 \mathrm{~g}$ deionized water, dried at $383 \mathrm{~K}$ for $3 \mathrm{~h}$, and calcined at $673 \mathrm{~K}$ for $4.5 \mathrm{~h}$ in stagnant air. The sample was denoted as $\mathrm{Mn} / \mathrm{Rh} / \mathrm{Ti} / \mathrm{SiO}_{2}-673$.

$2 \mathrm{~g} \mathrm{Mn} / \mathrm{Rh} / \mathrm{Ti} / \mathrm{SiO}_{2}-673$ was impregnated with a aqueous mixture of $0.010 \mathrm{~g} \mathrm{LiCl} \cdot \mathrm{H}_{2} \mathrm{O}, 0.112 \mathrm{~g} \mathrm{C}_{6} \mathrm{H}_{8} \mathrm{O}_{7}$ and $1.22 \mathrm{~g}$ deionized water, dried at $383 \mathrm{~K}$ for $3 \mathrm{~h}$, and calcined at $673 \mathrm{~K}$ for $4.5 \mathrm{~h}$ in stagnant air. The sample was denoted as $\mathrm{Li} / \mathrm{Mn} / \mathrm{Rh} / \mathrm{Ti} / \mathrm{SiO}_{2}-673$, and abbreviated as CAT-I-673. For the preparation of CAT-I-773 $\left(\mathrm{Li} / \mathrm{Mn} / \mathrm{Rh} / \mathrm{Ti} / \mathrm{SiO}_{2}-\right.$ 773), all the steps were the same as that of CAT-I-673, except changing the calcination temperature of section '2.22' to $773 \mathrm{~K}$.

For the preparation of CAT-II-673 (Li/Rh/Mn/Ti/SiO ${ }_{2}^{-}$ $673)$, all the preparation conditions were the same as that of CAT-I-673, except that the impregnation sequence of $\mathrm{Mn}$ and $\mathrm{Rh}$ was opposite.

\subsection{Characterization}

The $\mathrm{N}_{2}$ adsorption-desorption measurements were performed by using Micromeritics Tristar 3020 apparatus at $77 \mathrm{~K}$. Prior to measurement, samples were degassed under vacuum at $423 \mathrm{~K}$ overnight. The $\mathrm{Rh}, \mathrm{Mn}$, and Li contents in the samples were measured by atomic adsorption spectroscopy (AAS) (Analyst 200, Perkin Elmer, USA).

Transmission electron microscopy (TEM) characterization was performed by using a Talos F200X microscope (FEI, Hillsboro, OR, USA) at an acceleration voltage of $200 \mathrm{kV}$.

$\mathrm{X}$-ray diffraction (XRD) patterns were recorded on a Bruker D8 Advance X-ray diffractometer equipped with a Co $K \alpha$ radiation $(\lambda=0.179026 \mathrm{~nm})$ in the $2 \theta$ region between $20^{\circ}$ and $80^{\circ}$.

Temperature-programmed reduction in hydrogen (TPR $\left(\mathrm{H}_{2}\right)$ ) was performed in a homemade fixed bed reactor system connected to a thermal conductivity detector (TCD) to monitor the consumption of hydrogen by the as-prepared catalysts. $50 \mathrm{mg}$ of fresh catalyst was heated in a flow of 10 vol \% $\mathrm{H}_{2} / \mathrm{Ar}(30 \mathrm{ml} / \mathrm{min}$ ) from ambient temperature to $700 \mathrm{~K}$ at a heating rate of $5 \mathrm{~K} / \mathrm{min}$.

In-situ DRIFTS of CO adsorption was performed in a Nicolet 6700 FT-IR (Thermo Scientific) equipped with a MCD/A detector. Samples were reduced by pure $\mathrm{H}_{2}$ flow $\left(20 \mathrm{~cm}^{3} / \mathrm{min}\right)$ at $673 \mathrm{~K}$ for $15 \mathrm{~min}(5 \mathrm{~K} / \mathrm{min})$. Afterwards, the cell was evacuated with $\mathrm{He}$ at $673 \mathrm{~K}$ for $20 \mathrm{~min}$ to remove the adsorbed $\mathrm{H}_{2}$ molecules on the catalyst surface, followed by cooling down to $308 \mathrm{~K}$ under He flow $\left(20 \mathrm{~cm}^{3} / \mathrm{min}\right)$. Then $1.5 \mathrm{vol} \% \mathrm{CO} / \mathrm{He}$ $\left(20 \mathrm{~cm}^{3} / \mathrm{min}\right.$ ) was fed to the cell for $20 \mathrm{~min}$ at $308 \mathrm{~K}$. Subsequently, the catalysts were flushed in $\mathrm{He}\left(20 \mathrm{~cm}^{3} / \mathrm{min}\right)$ for $20 \mathrm{~min}$. Then the IR spectra were consecutively collected at different temperatures.

\subsection{Catalyst Performance}

Catalyst activity tests were performed in a six-flow fixed-bed microreactor (FBM) setup as previously described [42]. Prior to the operation, $100 \mathrm{mg}$ fresh catalysts $(50-100 \mu \mathrm{m})$ mixed with $\mathrm{SiC}$ were activated in situ by $\mathrm{H}_{2}$ at $593 \mathrm{~K}$ for $2.5 \mathrm{~h}$ at atmospheric pressure, followed by cooling to $473 \mathrm{~K}$ under $\mathrm{H}_{2}$. As the pressure was increased to 20 bar, feed composition was changed from $\mathrm{H}_{2}$ to a mixture of $\mathrm{H}_{2}, \mathrm{CO}$ and $\mathrm{N}_{2}$ in total of $40 \mathrm{ml} / \mathrm{min}$ (molar ratio: $\mathrm{H}_{2}: \mathrm{CO} ; \mathrm{N}_{2}=10: 5: 6$ ) at $473 \mathrm{~K}$. Then the reactor was heated to different reaction temperature with a heating rate of $2 \mathrm{~K} / \mathrm{min}$. All the reactions were run for $8 \mathrm{~h}$, after which a steady state was achieved, and products were analyzed after $8 \mathrm{~h}$ time-on-stream (TOS) using an online GC (Trace GC-Interscience). Methanol, acetaldehyde, ethanol and $\mathrm{C} 2-\mathrm{C} 3$ hydrocarbon were detected by a flame ionization detector (FID), while $\mathrm{H}_{2}, \mathrm{CO}, \mathrm{CO}_{2}$, and $\mathrm{CH}_{4}$ were analyzed by a thermal conductivity detector (TCD). Products selectivity was calculated from each component detected via online GC using $\mathrm{N}_{2}$ as an internal standard, from the total amount of $\mathrm{CO}$ converted. 


\section{Results and Discussion}

\subsection{Characterization of the As-Synthesized Catalysts}

The textural properties of $\mathrm{SiO}_{2}$ support and as-synthesized supported $\mathrm{Rh}$ catalysts were determined by $\mathrm{N}_{2}$ sorption method (Fig. S1). The $\mathrm{SiO}_{2}$ support exhibits a mesoporous structure, as proved by the type IV curve with type $\mathrm{H}_{2}$ hysteresis that closes at $P / P_{0} \approx 0.4$ in the $\mathrm{N}_{2}$ adsorption-desorption isotherms, demonstrating the presence of ink-bottle shape of pores. After stepwise impregnation and calcination treatments, the shape of isotherms did not change, while the BET surface area $(S)$ and pore volume $(V)$ of catalysts slightly decreased compared to the original $\mathrm{SiO}_{2}$ (Table S1). The small differences can be probably due to the blockage of pores by nanoparticles and/or collapse of pore structure during high temperature treatment. Elemental analysis confirms a similar content of rhodium, manganese, and lithium in these as-synthesized supported rhodium catalysts (Table S1).

Freshly prepared supported rhodium catalysts were further studied by transmission electron microscopy technique (TEM) combined with energy-dispersive X-ray spectroscopy (EDX). After the deposition of Ti precursor followed by a thermal treatment, uniformly dispersed $\mathrm{TiO}_{2}$ on $\mathrm{SiO}_{2}$ surface is observed (Fig. S2). Since $\mathrm{TiO}_{2}$ is known to contain a large number of surface hydroxyl groups, these hydroxyl groups can provide anchors for rhodium precursors, stabilize rhodium nanoparticles, and impede their growth and agglomeration during the subsequent thermal treatment [26]. Indeed, the presence of a thin layer of $\mathrm{TiO}_{2}$ on the surface of $\mathrm{SiO}_{2}$ to a large extent improve the dispersion of $\mathrm{Rh}_{2} \mathrm{O}_{3}$ nanoparticles compared to that in a similar $\mathrm{Rh} / \mathrm{SiO}_{2}$ catalyst (Fig. S3a, b). In the multicomponent promoted $\mathrm{Rh}$ catalysts, the $\mathrm{Rh}$ particle size and distribution largely depend on the calcination temperature. CAT-I-673 and CAT-II-673 show a homogenous distribution of $\mathrm{Rh}_{2} \mathrm{O}_{3}$ nanoparticles with an average $\mathrm{Rh}$ nanoparticle size around $\sim 1.5 \mathrm{~nm}$ (Fig. 1a, b). Further raising the calcination temperature to $773 \mathrm{~K}$ leads to an increase of $\mathrm{Rh}$ nanoparticle size to $2.8 \mathrm{~nm}$, with some large clusters consisting of small $\mathrm{Rh}_{2} \mathrm{O}_{3}$ crystals (Fig. 1c). EDX analysis displays overlapping signals of $\mathrm{Rh}$ and $\mathrm{Mn}$ on $\mathrm{TiO}_{2} /$ $\mathrm{SiO}_{2}$, and a close interaction between $\mathrm{Rh}$ and $\mathrm{Mn}$ can be expected. The small size of rhodium oxide nanoparticles is
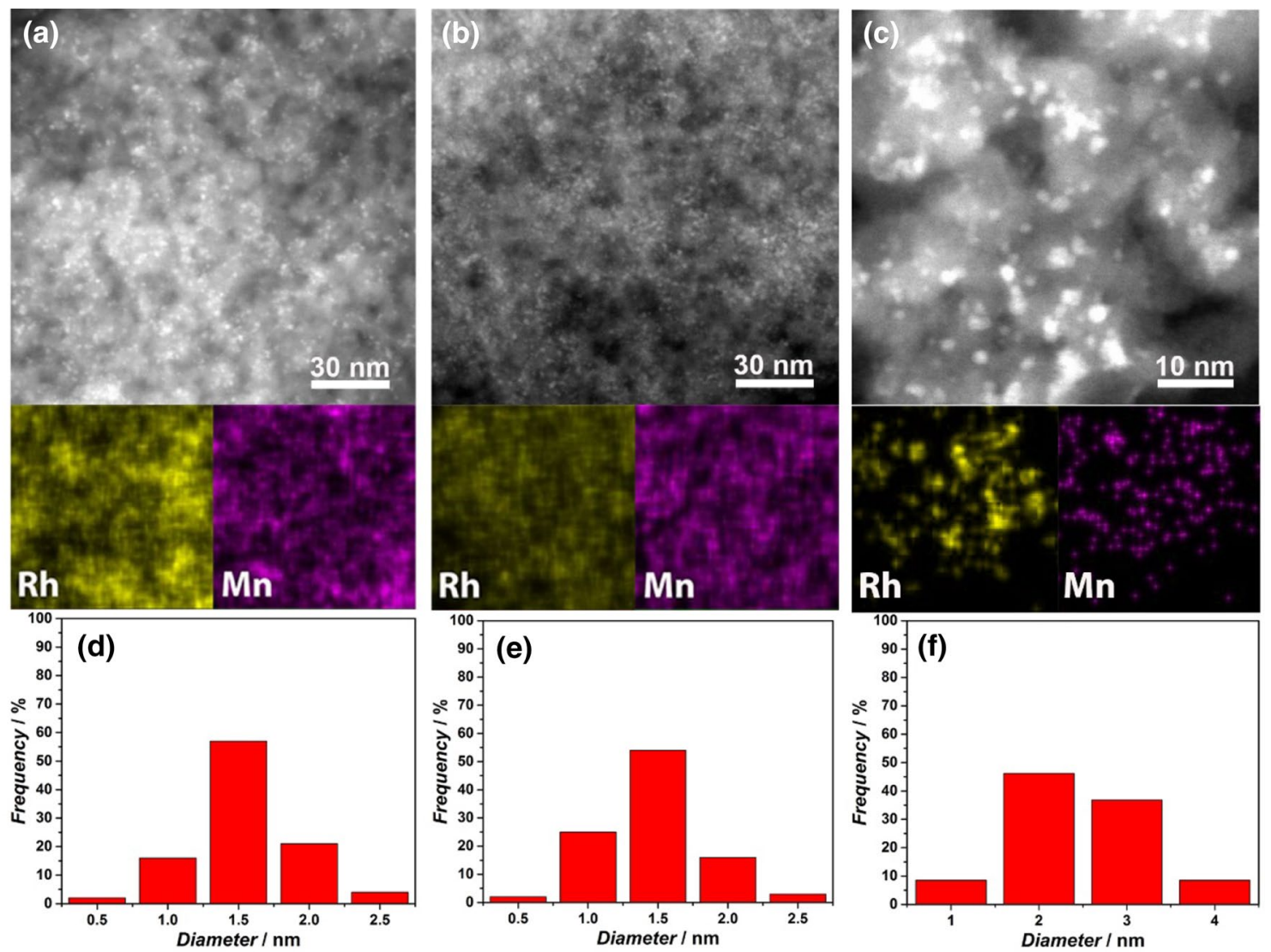

Fig. 1 Dark field TEM images and Rh particle size distribution of a, d; CAT-I-673; b, e CAT-II-673; and c, f CAT-I-773 catalysts, with element distribution of Rh and Mn 
further supported by the powder XRD analysis. As shown in Fig. 2a, the characteristic diffraction peaks for $\mathrm{Rh}_{2} \mathrm{O}_{3}$ (104) and (110) planes at $2 \theta$ value of $\sim 38$ and $\sim 41^{\circ}$ are broad and small, confirming the high dispersion. At the same time, the absence of diffraction peaks for $\mathrm{Mn}$ and $\mathrm{Li}$ species can be ascribed to their highly dispersed states and low loadings in these samples.

The reducibility of Rh species in all these as-synthesized samples was studied by temperature-programmed reduction in $\mathrm{H}_{2}$ [TPR $\left.\left(\mathrm{H}_{2}\right)\right]$. As present in Fig. 2b, only one reduction peak is observed in all these Rh-based catalysts, attributed to the reduction of rhodium oxide to its metallic phase [43, 44]. The reduction profiles of $\mathrm{Rh}$ depend on the impregnation sequence of $\mathrm{Mn}$ and $\mathrm{Rh}$ precursors and the calcination temperature. CAT-I-673 and CAT-II-673 exhibit a sharp reduction peak, suggesting that supported $\mathrm{Rh}_{2} \mathrm{O}_{3}$ nanoparticles in each sample have similar properties, supporting the narrow Rh particle size distribution. CAT-I-673 exhibits a higher temperature for Rh reduction than that of CAT-II-673, indicative for a stronger interaction between $\mathrm{Mn}$ and $\mathrm{Rh}$ in CATI-673. Moreover, further raising calcination temperature to $773 \mathrm{~K}$ shifts the reduction peak to a high temperature, and leads to a much broader peak than that in CAT-I-673, supporting the heterogeneity of Rh particle size distribution.

FTIR spectroscopy of adsorbed CO has been widely employed to study the nature of surface sites in most transition metal based catalysts due to the sensitivity of the $\mathrm{CO}$ stretching frequency to the electronic state of the adsorption sites [11]. Figure 3 together with Fig. S4 show the results obtained applying this $\mathrm{CO}$ adsorption technique on all these as-synthesized catalysts. No obvious $\mathrm{CO}$ adsorption bands can be observed from $\mathrm{SiO}_{2}$ support itself (Fig. S4a). The rhodium-based catalysts exhibit similar features, as shown in Figs. 3a-d and S4b-d. Two regions at $2150-1950 \mathrm{~cm}^{-1}$ and $1950-1650 \mathrm{~cm}^{-1}$ are clearly observed in the spectra of pre-adsorbed CO. In the region of $2150-1950 \mathrm{~cm}^{-1}$, the band centered at $\sim 2070 \mathrm{~cm}^{-1}$ is attributed to the linearly adsorbed $\mathrm{CO}$ on $\mathrm{Rh}^{0}$ sites [CO(1)], and the doublet at $\sim 2102 \mathrm{~cm}^{-1}$ and $\sim 2038 \mathrm{~cm}^{-1}$ can be assigned to the symmetric and asymmetric stretching vibration of a gemdicarbonyl $\mathrm{Rh}^{+}(\mathrm{CO})_{2}$, [CO(gdc)] [45]. No bands around $2145 \mathrm{~cm}^{-1}$ and $2135 \mathrm{~cm}^{-1}$ are detected, indicative of the absence of $\mathrm{Rh}^{3+}$ and $\mathrm{Rh}^{2+}$ species in these samples [45].

The feature of these $\mathrm{CO}$ adsorption bands varies with an increase of temperature, especially in the range of $2150-1950 \mathrm{~cm}^{-1}$. Taking the ' -773 ' samples for instance, the band of linearly adsorbed $\mathrm{CO}$ gradually becomes weaker together with an obvious shift of the intensity maximum to a lower wavenumber as the temperature increases, owning to a weaker dipolar coupling between $\mathrm{CO}$ molecules at a lower $\mathrm{CO}$ surface coverage. Although the intensity of gemdicarbonyl $\mathrm{Rh}^{+}(\mathrm{CO})_{2}$ signals decreases with temperature as well, the bands stay at the identical position. The development of these dicarbonyl complex bands demonstrates that these adsorption sites are spatially isolated, since close proximity of adsorbed $\mathrm{CO}$ molecules is supposed to lead to dipole-dipole interaction and, therefore, a shift to lower wavenumbers as surface coverage should decrease [45]. Furthermore, the representative signals of $\mathrm{Rh}^{+}(\mathrm{CO})_{2}$ gradually decrease with an increase of temperature, indicative of a weak adsorption energy of $\mathrm{CO}$ molecules on these rhodium sites. The feature of these $\mathrm{CO}$ adsorption bands varies with the composition in the catalysts as well. $\mathrm{Rh}-\mathrm{Ti} / \mathrm{SiO}_{2}-773$ exhibits a higher fraction of $\mathrm{CO}(\mathrm{gdc})$ species than that of $\mathrm{Mn}-\mathrm{Rh}-\mathrm{Ti} / \mathrm{SiO}_{2}-773$ and CAT-I-773. The presence of $\mathrm{Li}$ in CAT-I-773 improves the adsorption strength of the $\mathrm{CO}(\mathrm{gdc})$ species, as proven by the presence of $\mathrm{CO}$ adsorption band at $\sim 2102 \mathrm{~cm}^{-1}$ at $423 \mathrm{~K}$.

In the region of $1950-1650 \mathrm{~cm}^{-1}$, a broad shoulder with a tail is present, suggesting the existence of several kinds of
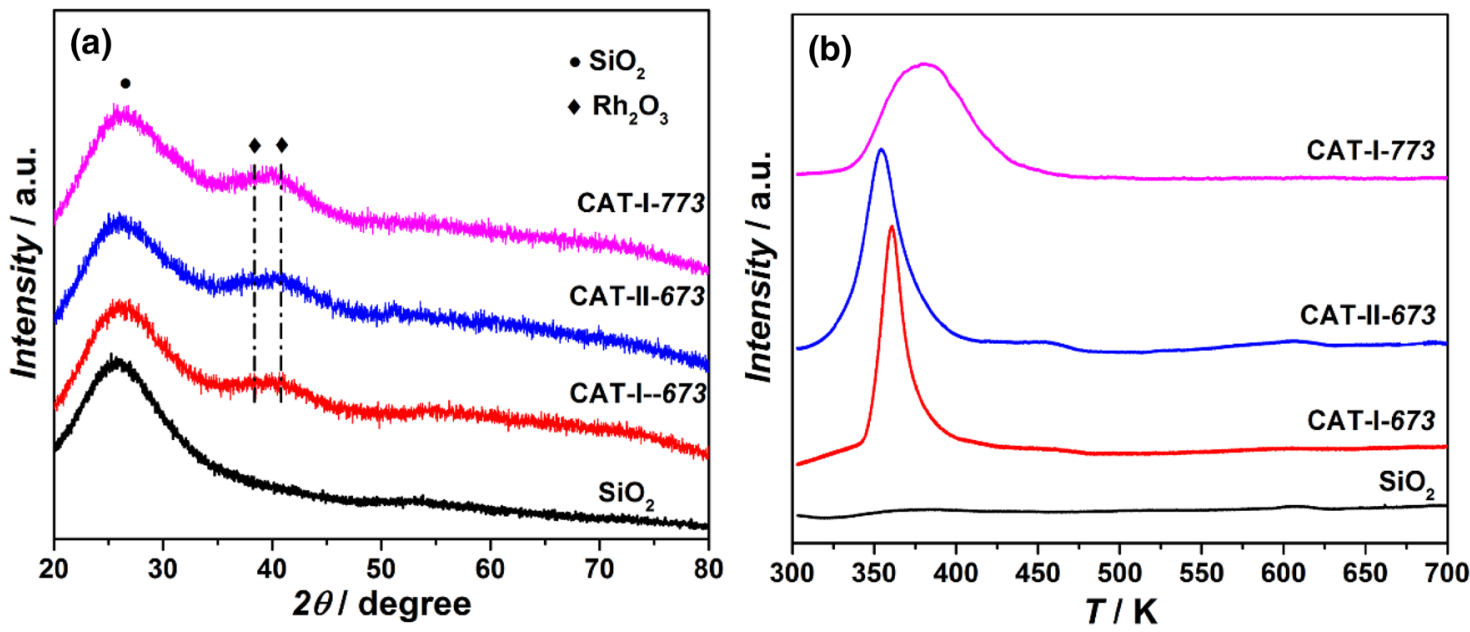

Fig. 2 a XRD patterns and b TPR $\left(\mathrm{H}_{2}\right)$ profiles of the as-synthesized supported Rh catalysts 

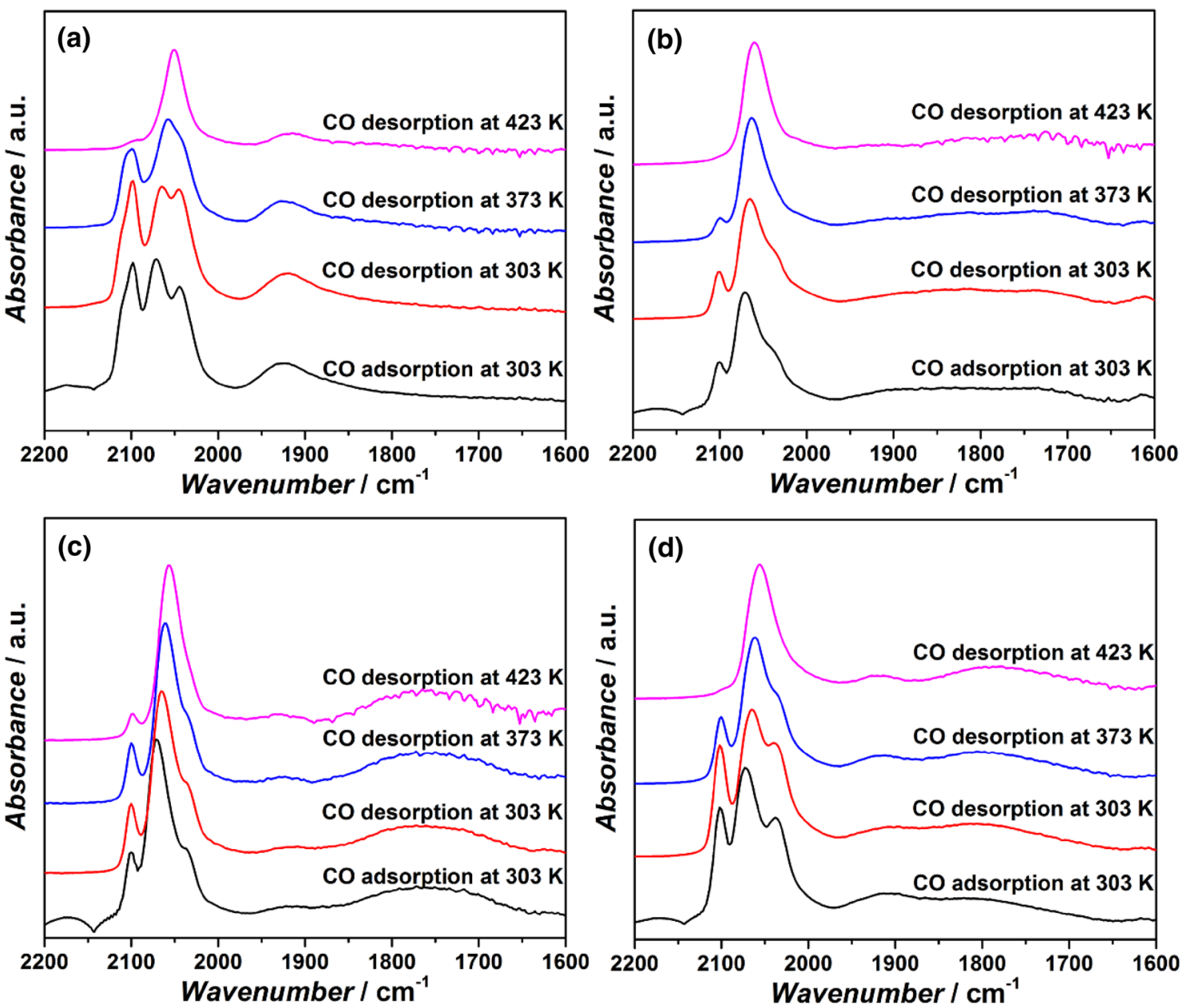

Fig. 3 DRIFT spectra of $\mathrm{CO}$ adsorbed on a Rh-Ti/SiO ${ }_{2}^{-773, ~ b ~ M n-R h-T i / S i O}{ }_{2}-773$, c CAT-I-773, and d CAT-I-673 catalysts at different temperatures

$\mathrm{CO}$ adsorption sites at the surface of rhodium nanoparticles. Specifically, the broad bands between 1950 and $1750 \mathrm{~cm}^{-1}$ represent the existence of bridge bonded $\mathrm{CO}$ on $\mathrm{Rh}^{0}[46]$. The tail with a wavenumber ranging from $1750 \mathrm{~cm}^{-1}$ to $1650 \mathrm{~cm}^{-1}[\mathrm{CO}(\mathrm{t})]$ is too low to be attributed to CO bridgebonded to several $\mathrm{Rh}$ atoms via carbon atom alone. Similar bands at $1725 \mathrm{~cm}^{-1}$ and $1696 \mathrm{~cm}^{-1}$ were also detected by Lisitsyn et al. [21] These bridging sites have been considered as the metal/oxide interfacial sites, on which the $\mathrm{C}$ and $\mathrm{O}$ in $\mathrm{CO}$ molecule are bonded to metallic $\mathrm{Rh}$ and $\mathrm{Mn}^{\delta+}$ cation, respectively, namely a tilted $\mathrm{Rh}-\mathrm{C}-\mathrm{O}-\mathrm{Mn}$ species $[21,38$, 47]. Such an adsorption state should weaken the $\mathrm{C}-\mathrm{O}$ bond and enhance $\mathrm{CO}$ dissociation.

Finally, the intensity ratio between $\mathrm{CO}(\mathrm{l})$ and $\mathrm{CO}(\mathrm{gdc})$ bands varies between catalysts prepared at different temperatures. The ' -673 ' samples show a similar $\mathrm{CO}(\mathrm{l}) / \mathrm{CO}(\mathrm{gdc})$ value but lower than that of the ' -773 ' sample (Figs. 3c, $\mathrm{d}$ and $\mathrm{S} 4 \mathrm{~d}$ ). Since the dicarbonyl $\mathrm{Rh}^{+}$species are predominantly formed on highly dispersed rhodium nanoparticles, the relatively higher intensity of the dicarbonyl bands in the ' -673 ' samples further supports the smaller rhodium size than that in the ' -773 ' sample $[19,29]$. In contrast, the intensity ratio between $\mathrm{CO}(\mathrm{l})$ and $\mathrm{CO}(\mathrm{t})$ for the ' -673 ', samples is higher than that in the ' -773 ' sample, indicative of a higher fraction of tilted $\mathrm{Rh}-\mathrm{C}-\mathrm{O}-\mathrm{Mn}$ species on the '-773' surface.

\subsection{Roles of Rh Particle Size and Promoters on Hydrogenation Activity and Products Selectivity}

$\mathrm{CO}$ conversions over these supported $\mathrm{Rh}$ catalysts after $8 \mathrm{~h}$ time-on-stream (TOS) (after which $\mathrm{CO}$ conversion becomes stable) at $533 \mathrm{~K}, 20 \mathrm{bar}, \mathrm{H}_{2} / \mathrm{CO}$ molar ratio of 2 are presented in Fig. 4a. The catalytic performance of these $\mathrm{Rh}$-based catalysts displays different $\mathrm{CO}$ conversion levels. CAT-I-773 shows a higher CO conversion (3.9\%) than that of the CAT-I-673 (2.3\%) and CAT-II-673 (1.2\%). In 

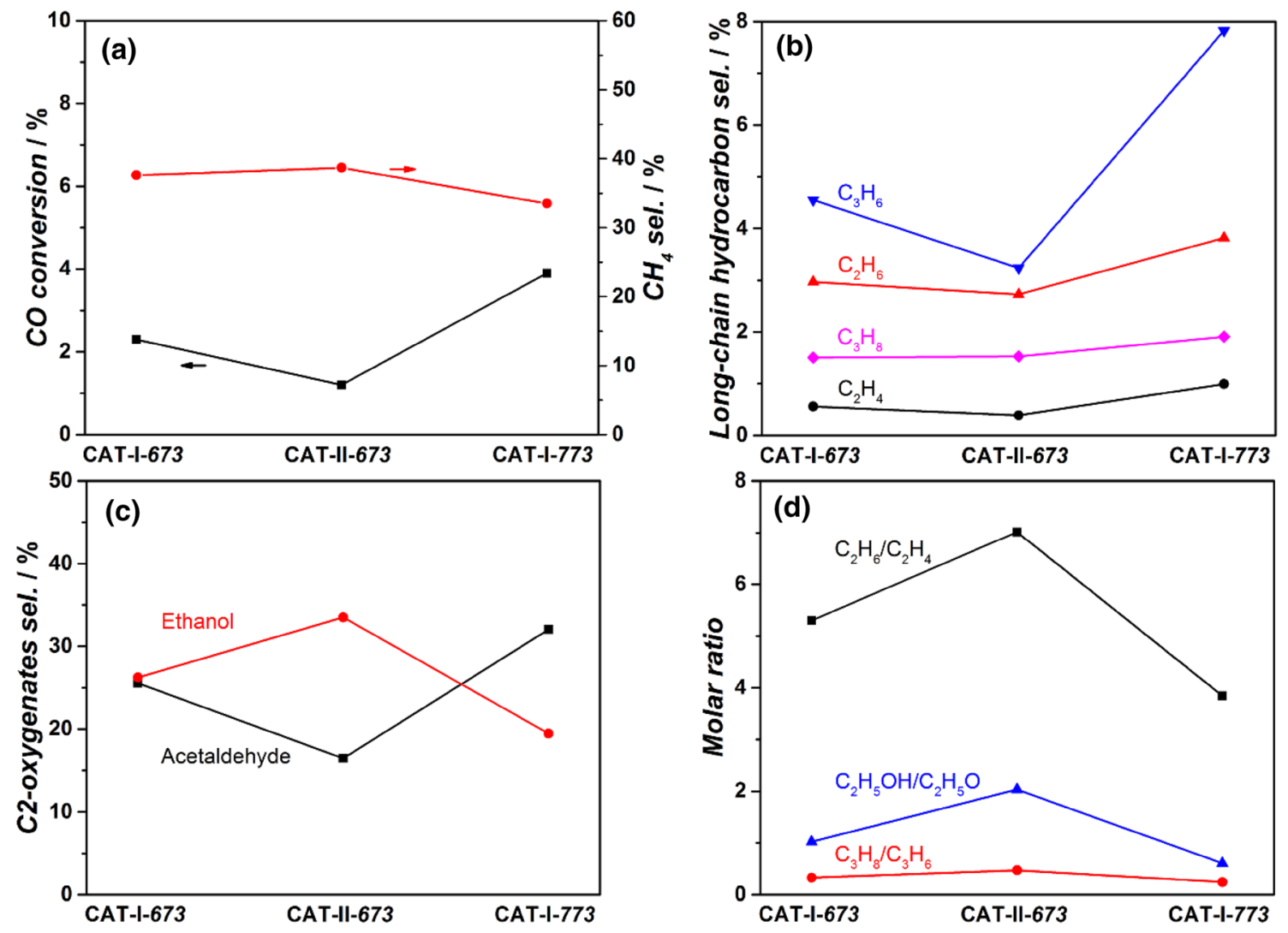

Fig. 4 a $\mathrm{CO}$ conversion and $\mathrm{CH}_{4}$ selectivity; b long-chain hydrocarbon selectivity; $\mathbf{c} \mathrm{C} 2$-oxygenates selectivity and $\mathbf{d}$ products molar ratio for CAT-I-673, CAT-II-673, and CAT-I-773 catalysts after $8 \mathrm{~h}$ TOS at $533 \mathrm{~K}, 20$ bar total pressure, and feed composition $\mathrm{H}_{2} / \mathrm{CO}=2$

principle, small Rh nanoparticles in CAT-I-673 exhibit a much stronger interaction with the thin $\mathrm{TiO}_{2}$ layer on $\mathrm{SiO}_{2}$ support compared to the large ones in CAT-I-773 [11, 20]. The strong $\mathrm{Rh}-\mathrm{TiO}_{2}$ interaction generates a large number of electron-deficient $\mathrm{Rh}$ atoms on the surface, which results in poor electron back-donation to the unoccupied $2 \pi^{*}$ antibonding orbital of $\mathrm{CO}$, thereby impeding $\mathrm{CO}$ dissociation and further hydrogenation. Moreover, $\mathrm{MnO}$ promoter has also been reported to improve the hydrogenation activity of supported Rh catalysts [32, 48]. For instance, Wang et al. found that adding $1.1 \mathrm{wt} \% \mathrm{Mn}$ to a carbon nanotubes(CNTs) supported $4.5 \mathrm{wt} \% \mathrm{Rh}$ catalyst led to a $\mathrm{CO}$ conversion two times as high as that of $4.5 \mathrm{wt} \% \mathrm{Rh} / \mathrm{CNTs}$ [48]. Schwartz et al. also reported a similar trend after introducing $0.5 \mathrm{wt} \%$ $\mathrm{Mn}$ into $1 \mathrm{wt} \% \mathrm{Rh} / \mathrm{TiO}_{2}$ [26]. In general, hydrogenation of $\mathrm{CO}$ to formyl species intermediate is considered as the rate limiting step on $\mathrm{Rh}$-based catalyst [30, 49]. The introduction of $\mathrm{Mn}$ species can generate $\mathrm{Rh}-\mathrm{MnO}$ interfacial sites on the surface of Rh nanoparticles. CO molecules adsorb on these sites in a tilted $\mathrm{Rh}-\mathrm{C}-\mathrm{O}-\mathrm{Mn}$ mode, which shows a high $\mathrm{CO}$ dissociation activity $[38,47]$. Obviously, the larger Rh nanoparticle size and the higher fraction of tilted $\mathrm{Rh}-\mathrm{C}-\mathrm{O}-\mathrm{Mn}$ species in CAT-I-773 than the '-673' samples lead to a higher hydrogenation activity.
The products distributions for all these $\mathrm{Rh}$ based catalysts after $8 \mathrm{~h}$ are included in Fig. 4a-d. Negligible $\mathrm{CO}_{2}$ and methanol was detected in all these as-synthesized $\mathrm{Rh}$ based catalysts under this experimental condition. Previous studies demonstrated that both metallic and partially positive $\mathrm{Rh}$ sites are necessary in the production of C2-oxygenates $[15,50]$. Metallic $\mathrm{Rh}\left(\mathrm{Rh}^{0}\right)$ was considered for $\mathrm{C}-\mathrm{O}$ bonds dissociation to produce ' $-\mathrm{CH}_{\mathrm{x}}$ ' species, and positive $\mathrm{Rh}$ $\left(\mathrm{Rh}^{\delta+}\right)$ was responsible for $\mathrm{CO}$ insertion [15]. In this sense, parameters that can adjust the molar ratio of $\mathrm{Rh}^{0} / \mathrm{Rh}^{\delta+}$ in $\mathrm{Rh}$ nanoparticles are supposed to influence products distribution [27, 29]. Haider et al. proved that $\mathrm{Rh} / \mathrm{SiO}_{2}$ with a weak Rh-support interaction mainly produces hydrocarbons, while more $\mathrm{C} 2$-oxygenates were detected on $\mathrm{Rh} / \mathrm{TiO}_{2}$ with a strong-metal-support-interaction (SMSI) at the expense of hydrocarbons [27]. The improvement in C2-oxygenates production on $\mathrm{TiO}_{2}$ was attributed to its stronger interaction with $\mathrm{Rh}$ nanoparticles, which creates more $\mathrm{Rh}^{\delta+}$ sites. Similarly in the current work, the thin $\mathrm{TiO}_{2}$ layer on $\mathrm{SiO}_{2}$ support interacts strongly with Rh nanoparticles, and generates numerous partially positive $\mathrm{Rh}$ sites necessary for $\mathrm{CO}$ insertion in $\mathrm{C} 2$-oxygenates production. Besides, the particle size of supported $\mathrm{Rh}$ nanoparticles can also influence the molar ratio of $\mathrm{Rh}^{0} / \mathrm{Rh}^{\delta+}$ at the surface of $\mathrm{Rh}$ nanoparticles. 
In general, as Rh nanoparticles become smaller, the electron-interaction between the support and Rh nanoparticles becomes stronger, and more electrons from $\mathrm{Rh}$ can be withdrawn by the support; hence more $\mathrm{Rh}^{\delta+}$ sites at the surface can be created. Indeed, the ' -673 ' samples exhibit a much higher fraction of $\mathrm{Rh}^{\delta+}$ sites than CAT-I-773, as confirmed in Fig. 2c. Previous study by Hironori et al. reported a volcano-like relationship between $\mathrm{Rh}$ nanoparticle size and $\mathrm{C} 2$-oxygenates selectivity with the maximum $\mathrm{C} 2$-oxygenates selectivity at $\mathrm{Rh}$ particle size of $\sim 3.0 \mathrm{~nm}$ on a $\mathrm{Rh} / \mathrm{SiO}_{2}$ catalyst [51]. The CAT-I-773 catalyst with a similar Rh particle size $(\sim 2.8 \mathrm{~nm})$ also exhibits a higher C2-oxygenates (sum of acetaldehyde and ethanol) selectivity ( $\sim 55 \%)$ than the '-673' samples with a smaller Rh particle size of $\sim 1.5 \mathrm{~nm}(\sim 50 \%)$. At the same time, CAT-I-773 produces more C2-C4 hydrocarbons and less $\mathrm{CH}_{4}$ (33\% vs. 38\%) compared to CAT-I673, as shown in Fig. 4a, b. Indeed, large nanoparticles are known to contain more terrace sites for carbon chain growth towards long chain hydrocarbons instead of methane [52].

Beside the effects of the support and Rh particle size on products selectivity, the presence of $\mathrm{Li}$ and $\mathrm{Mn}$ in supported $\mathrm{Rh}$ catalysts is also of great importance for the production of
C2-oxygenates in this study. Egbebi et al. and Schwartz et al. indicated that a small amount of $\mathrm{Li}(\sim 0.1 \mathrm{wt} \%)$ significantly improved the products selectivity towards $\mathrm{C} 2$-oxygenates of $1 \mathrm{wt} \% \mathrm{Rh} / \mathrm{TiO}_{2}$ at the expense of $\mathrm{CH}_{4}$ production [25, 26]. The presence of $\mathrm{Li}$ was stated to improve the stability of the ' $-\mathrm{CH}_{\mathrm{x}}$ ' intermediate species on the surface of $\mathrm{Rh}$, making the insertion of adsorbed $\mathrm{CO}$ species into ' $-\mathrm{CH}_{\mathrm{x}}$ ' to produce $\mathrm{C} 2$-oxygenates more competitive than the direct hydrogenation of ' $-\mathrm{CH}_{\mathrm{x}}$ ' into methane $[25,40]$. Moreover, Liu et al. reported that the addition of $\mathrm{Mn}$ into $3 \mathrm{wt} \% \mathrm{Rh} /$ CNTs significantly promoted the production of C2-oxygenates, and C2-oxygenates selectivity seemed to increase with the loadings of $\mathrm{Mn}$ in the catalyst [32]. A similar phenomenon was as well observed by Schwartz et al. after introducing $0.5 \mathrm{wt} \% \mathrm{Mn}$ into a $1 \mathrm{wt} \% \mathrm{Rh} / \mathrm{TiO}_{2}$ catalyst [26]. Manganese species in oxidation states are well-known to act as electron acceptors and withdraw electrons from $\mathrm{Rh}$ to create partially positive $\mathrm{Rh}$ sites, necessary for $\mathrm{CO}$ insertion in $\mathrm{C} 2$-oxygenates production $[32,34]$. At the same time, the tilt-adsorbed $\mathrm{CO}$ species at the $\mathrm{Rh}-\mathrm{MnO}$ interfacial sites was reported by Wang et al. to be the precursor for the formation of oxygenates [53]. Interestingly, although CAT-I-673 and
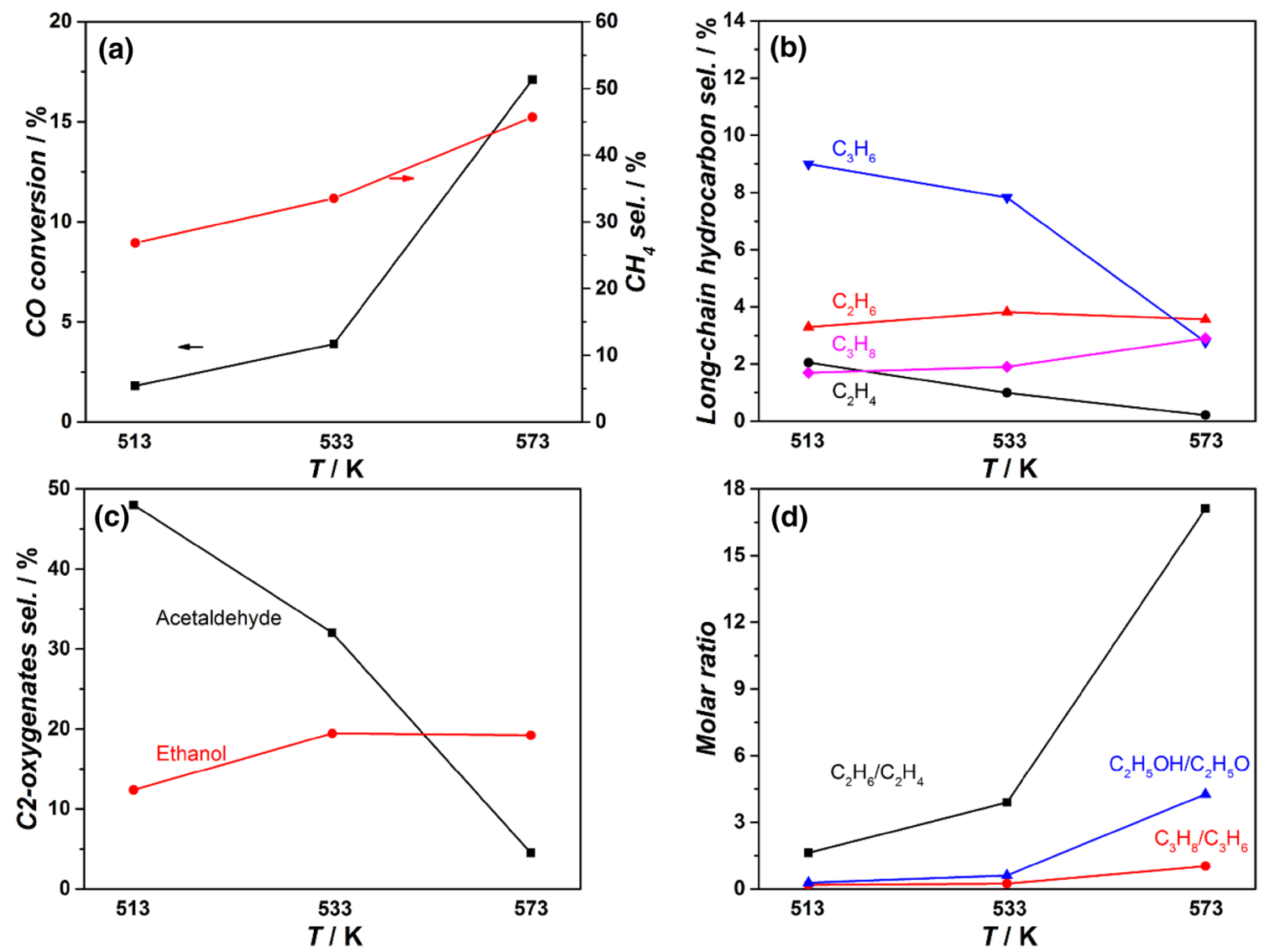

Fig. 5 a $\mathrm{CO}$ conversion and $\mathrm{CH}_{4}$ selectivity; b long-chain hydrocarbon selectivity; c C2-oxygenates selectivity and d products molar ratio for CAT-I-773 catalyst at different temperatures, 20 bar total pressure, and feed composition $\mathrm{H}_{2} / \mathrm{CO}=2$ 
CAT-II-673 show similar C2-oxygenates (sum of acetaldehyde and ethanol) selectivity, CAT-II-673 exhibits a higher ethanol selectivity (33\%) than CAT-I-673 (26\%), indicative of a higher hydrogenation capability of CAT-II-673 with $\mathrm{MnO}$ underneath $\mathrm{Rh}$ nanoparticles, as shown in Fig. $4 \mathrm{c}$, d. Indeed, $\mathrm{H}_{2}$-TPR profile of CAT-II-673 indicates that a lower reduction temperature is needed compared to that of CATI-673, suggestive of a relatively weaker interaction between $\mathrm{Rh}$ and manganese oxide and/or $\mathrm{TiO}_{2}$ in CAT-II-673. The higher hydrogenation ability of CAT-II- 673 can be also demonstrated by higher ethane/ethylene and propane/propylene ratios, as shown in Fig. 4 d.

\subsection{Influence of Reaction Variables: Temperature and $\mathrm{H}_{2}: \mathrm{CO}$ Ratio on Catalytic Performance}

The effect of reaction temperature on the hydrogenation activity and products selectivity of the representative CATI-773 sample is summarized in Fig. 5a-d. CO conversion increases from 1.8 to $17.1 \%$ as the reaction temperature increase from 513 to $573 \mathrm{~K}$, while the selectivity to paraffins, especially methane increases from $\sim 27$ to $\sim 46 \%$ at the expense of total olefins and C2-oxygenates selectivity, which decreases from 60 to $24 \%$. These results indicate a dominant hydrogenation of ' $-\mathrm{CH}_{\mathrm{x}}$ ' species at high temperature and the activation energy for methane formation is higher than that for C2-oxygenates synthesis [54]. The preferable hydrogenation reaction at high temperature is further proved by an increase of paraffin/olefin and/or ethanol/acetaldehyde ratio.

Figure 6 summarizes the influence of $\mathrm{H}_{2}$ : $\mathrm{CO}$ ratio ranging from 1 to 3 on the hydrogenation activity and products selectivity over CAT-I-773. As shown in Fig. 6a, c, despite that the $\mathrm{CO}$ conversion increases from 1.3 to $4.8 \%$ with $\mathrm{H}_{2}$ concentration in the feed, the selectivity to methane also increased from 27 to $44 \%$ at the expense of acetaldehyde, which decreases from 46 to $12 \%$. Indeed, a high concentration of hydrogen on the surface on one hand promotes the termination step of ' $-\mathrm{CH}_{\mathrm{x}}$ ' species, leading to high $\mathrm{CH}_{4}$ production; on the other hand enhances the hydrogenation steps of unsaturated $\mathrm{C}=\mathrm{C}$ and $\mathrm{C}=\mathrm{O}$ bonds, resulting in high product selectivity to paraffin and ethanol at the expense of olefins and acetaldehyde, as confirmed in Fig. 6b-d. These
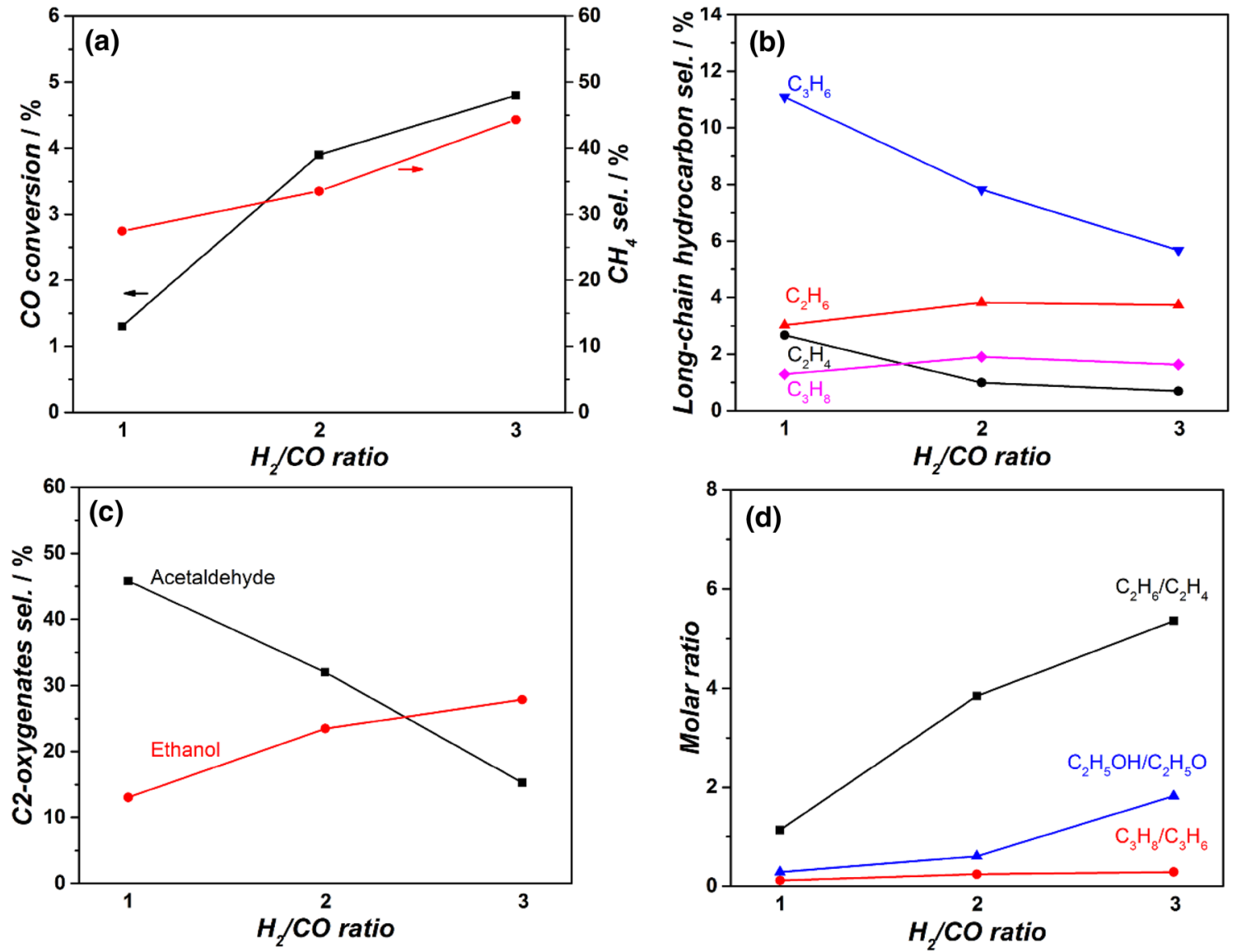

Fig. 6 a $\mathrm{CO}$ conversion and $\mathrm{CH}_{4}$ selectivity; b long-chain hydrocarbon selectivity; c C2-oxygenates selectivity and $\mathbf{d}$ products molar ratio for CAT-I-773 catalyst at $533 \mathrm{~K}, 20$ bar total pressure, and different feed compositions 
results suggest that to target $\mathrm{C} 2$-oxygenates synthesis, reaction is preferred to be operated at a low temperature with a low $\mathrm{H}_{2} / \mathrm{CO}$ molar ratio in the feed.

\section{Conclusions}

In this work, $\mathrm{Mn}$ and $\mathrm{Li}$ promoted $\mathrm{Rh}$ catalysts supported on $\mathrm{SiO}_{2}$ with a thin $\mathrm{TiO}_{2}$ layer were prepared by stepwise incipient wetness impregnation method. The thin $\mathrm{TiO}_{2}$ layer on the surface of $\mathrm{SiO}_{2}$ was crucial to stabilize those small $\mathrm{Rh}$ nanoparticles and hamper their agglomeration. The reducibility of $\mathrm{Rh}$ on these catalysts is dependent on both $\mathrm{Rh}$ particle size and the location of manganese oxide. Large $\mathrm{Rh}$ nanoparticles beneath $\mathrm{MnO}$ can be reduced at a higher temperature than small $\mathrm{Rh}$ nanoparticles on $\mathrm{MnO}$. Large $\mathrm{Rh}$ particles show a higher $\mathrm{CO}$ conversion and higher products selectivity towards long chain hydrocarbons and C2-oxygenates, but a lower methane selectivity compared to a similar catalyst with smaller Rh particles. The high catalytic performance to $\mathrm{C} 2$-oxygenates with large $\mathrm{Rh}$ nanoparticles is ascribed to both the promotion effect of $\mathrm{Mn}$ and $\mathrm{Li}$, and a proper molar ratio between metallic $\mathrm{Rh}\left(\mathrm{Rh}^{0}\right)$ sites and partially positive $\mathrm{Rh}\left(\mathrm{Rh}^{\delta+}\right)$ sites on the surface of $\mathrm{Rh}$ nanoparticles. Moreover, the catalyst with $\mathrm{MnO}$ underneath the $\mathrm{Rh}$ nanoparticles is more efficient in promoting hydrogenation of acetaldehyde to ethanol than a similar catalyst with $\mathrm{MnO}$ on $\mathrm{Rh}$ nanoparticles. In order to reach high $\mathrm{C} 2$-oxygenates selectivity, reaction is recommended to be performed at a low temperature together with a low $\mathrm{H}_{2} / \mathrm{CO}$ ratio in the feed.

Open Access This article is distributed under the terms of the Creative Commons Attribution 4.0 International License (http://creativeco mmons.org/licenses/by/4.0/), which permits unrestricted use, distribution, and reproduction in any medium, provided you give appropriate credit to the original author(s) and the source, provide a link to the Creative Commons license, and indicate if changes were made.

\section{References}

1. Rostrup-Nielsen JR (2005) Making fuels from biomass. Science 308:1421-1422

2. Schmidt LD, Dauenhauer PJ (2007) Hybrid routes to biofuels. Nature 447:914

3. Song C (2006) Global challenges and strategies for control, conversion and utilization of $\mathrm{CO}_{2}$ for sustainable development involving energy, catalysis, adsorption and chemical processing. Catal Today 115:2-32

4. Ahmed A, Lewis RS (2007) Fermentation of biomass-generated synthesis gas: effects of nitric oxide. Biotechnol Bioeng 97:1080-1086

5. Farrell AE, Plevin RJ, Turner BT, Jones AD, O’Hare M, Kammen DM (2006) Ethanol can contribute to energy and environmental goals. Science 311:506-508
6. Spivey JJ, Egbebi A (2007) Heterogeneous catalytic synthesis of ethanol from biomass-derived syngas. Chem Soc Rev 36:1514-1528

7. Subramani V, Gangwal SK (2008) A review of recent literature to search for an efficient catalytic process for the conversion of syngas to ethanol. Energy Fuels 22:814-839

8. Zaman S, Smith KJ (2012) A review of molybdenum catalysts for synthesis gas conversion to alcohols: catalysts, mechanisms and kinetics. Catal Rev 54:41-132

9. Vannice MA (1975) The catalytic synthesis of hydrocarbons from H2CO mixtures over the group VIII metals: I. The specific activities and product distributions of supported metals. J Catal 37:449-461

10. Poutsma ML, Elek LF, Ibarbia PA, Risch AP, Rabo JA (1978) Selective formation of methanol from synthesis gas over palladium catalysts. J Catal 52:157-168

11. Sun X, Sartipi S, Kapteijn F, Gascon J (2016) Effect of pretreatment atmosphere on the activity and selectivity of $\mathrm{Co} /$ mesoHZSM-5 for Fischer-Tropsch synthesis. New J Chem 40:4167-4177

12. Sun X, Suarez AIO, Meijerink M, van Deelen T, Ould-Chikh S, Zečević J, de Jong KP, Kapteijn F, Gascon J (2017) Manufacture of highly loaded silica-supported cobalt Fischer-Tropsch catalysts from a metal organic framework. Nat Commun 8:1680

13. Wezendonk TA, Sun X, Dugulan AI, van Hoof AJF, Hensen EJM, Kapteijn F, Gascon J (2018) Controlled formation of iron carbides and their performance in Fischer-Tropsch synthesis. J Catal 362:106-117

14. Cheng Q, Tian Y, Lyu S, Zhao N, Ma K, Ding T, Jiang Z, Wang L, Zhang J, Zheng L, Gao F, Dong L, Tsubaki N, Li X (2018) Confined small-sized cobalt catalysts stimulate carbon-chain growth reversely by modifying ASF law of Fischer-Tropsch synthesis. Nat Commun 9:3250

15. Watson PR, Somorjai GA (1981) The hydrogenation of carbon monoxide over rhodium oxide surfaces. J Catal 72:347-363

16. Bhasin MM, Bartley WJ, Ellgen PC, Wilson TP (1978) Synthesis gas conversion over supported rhodium and rhodium-iron catalysts. J Catal 54:120-128

17. Burch R, Petch MI (1992) Investigation of the synthesis of oxygenates from carbon monoxide/hydrogen mixtures on supported rhodium catalysts. Appl Catal A 88:39-60

18. Erdöhelyi A, Solymosi F (1983) Effects of the support on the adsorption and dissociation of $\mathrm{CO}$ and on the reactivity of surface carbon on Rh catalysts. J Catal 84:446-460

19. Basu P, Panayotov D, Yates JT (1988) Rhodium-carbon monoxide surface chemistry: the involvement of surface hydroxyl groups on alumina and silica supports. J Am Chem Soc 110:2074-2081

20. Ojeda M, Rojas S, Boutonnet M, Pérez-Alonso FJ, GarcíaGarcía FJ, Fierro JLG (2004) Synthesis of Rh nano-particles by the microemulsion technology: particle size effect on the $\mathrm{CO}+\mathrm{H}_{2}$ reaction. Appl Catal A 274:33-41

21. Lisitsyn AS, Stevenson SA, Knözinger H (1990) Carbon monoxide hydrogenation on supported Rh-Mn catalysts. J Mol Catal 63:201-211

22. Rives-Arnau V, Munuera G (1980) Effect of strong metalsupport interactions on the catalytic reduction of NO by $\mathrm{TiO}_{2}$-supported rhodium. Appl Surf Sci 6:122-137

23. Gajardo P, Gleason EF, Katzer JR, Sleight AW (1981) Preparation and characterization of highly dispersed rhodium on $\mathrm{Al}_{2} \mathrm{O}_{3}$, $\mathrm{TiO}_{2}, \mathrm{ZrO}_{2}$, and $\mathrm{CeO}_{2}$. In: Seiyama T, Tanabe K (eds) Studies in surface science and catalysis. Elsevier, Amsterdam, pp $1462-1463$

24. Vis JC, Van't Buk HFJ, Huizinga T, Van Grondelle J, Prins $\mathrm{R}$ (1984) Reduction and oxidation of $\mathrm{Rh} / \mathrm{Al}_{2} \mathrm{O}_{3}$ and $\mathrm{Rh} / \mathrm{TiO}_{2}$ catalysts as studied by temperature-programmed reduction and oxidation. J Mol Catal 25:367-378 
25. Egbebi A, Schwartz V, Overbury SH, Spivey JJ (2010) Effect of $\mathrm{Li}$ promoter on titania-supported $\mathrm{Rh}$ catalyst for ethanol formation from CO hydrogenation. Catal Today 149:91-97

26. Schwartz V, Campos A, Egbebi A, Spivey JJ, Overbury SH (2011) EXAFS and FT-IR characterization of Mn and Li promoted titania-supported $\mathrm{Rh}$ catalysts for $\mathrm{CO}$ hydrogenation. ACS Catal 1:1298-1306

27. Haider MA, Gogate MR, Davis RJ (2009) Fe-promotion of supported Rh catalysts for direct conversion of syngas to ethanol. J Catal 261:9-16

28. Palomino RM, Magee JW, Llorca J, Senanayake SD, White MG (2015) The effect of $\mathrm{Fe}-\mathrm{Rh}$ alloying on $\mathrm{CO}$ hydrogenation to $\mathrm{C} 2+$ oxygenates. J Catal 329:87-94

29. Gao J, Mo X, Chien AC-Y, Torres W, Goodwin JG (2009) CO hydrogenation on lanthana and vanadia doubly promoted $\mathrm{Rh} / \mathrm{SiO}_{2}$ catalysts. J Catal 262:119-126

30. Yang N, Yoo JS, Schumann J, Bothra P, Singh JA, Valle E, AbildPedersen F, Nørskov JK, Bent SF (2017) Rh-MnO interface sites formed by atomic layer deposition promote syngas conversion to higher oxygenates. ACS Catal 7:5746-5757

31. Bezemer GL, Radstake PB, Falke U, Oosterbeek H, Kuipers HPCE, van Dillen AJ, de Jong KP (2006) Investigation of promoter effects of manganese oxide on carbon nanofiber-supported cobalt catalysts for Fischer-Tropsch synthesis. J Catal 237:152-161

32. Liu J, Guo Z, Childers D, Schweitzer N, Marshall CL, Klie RF, Miller JT, Meyer RJ (2014) Correlating the degree of metal-promoter interaction to ethanol selectivity over $\mathrm{MnRh} / \mathrm{CNTs} \mathrm{CO}$ hydrogenation catalysts. J Catal 313:149-158

33. Mei D, Rousseau R, Kathmann SM, Glezakou V-A, Engelhard MH, Jiang W, Wang C, Gerber MA, White JF, Stevens DJ (2010) Ethanol synthesis from syngas over Rh-based/ $\mathrm{SiO}_{2}$ catalysts: a combined experimental and theoretical modeling study. J Catal 271:325-342

34. van den Berg FGA, Glezer JHE, Sachtler WMH (1985) The role of promoters in $\mathrm{COH}_{2}$ reactions: effects of $\mathrm{MnO}$ and $\mathrm{MoO}_{2}$ in silica-supported rhodium catalysts. J Catal 93:340-352

35. Wang Y, Song Z, Ma D, Luo H, Liang D, Bao X (1999) Characterization of Rh-based catalysts with EPR, TPR, IR and XPS. J Mol Catal A 149:51-61

36. Wilson TP, Kasai PH, Ellgen PC (1981) The state of manganese promoter in rhodium-silica gel catalysts. J Catal 69:193-201

37. Ojeda M, Granados ML, Rojas S, Terreros P, García-García FJ, Fierro JLG (2004) Manganese-promoted $\mathrm{Rh} / \mathrm{Al}_{2} \mathrm{O}_{3}$ for C2-oxygenates synthesis from syngas: effect of manganese loading. Appl Catal A 261:47-55

38. Brundage MA, Balakos MW, Chuang SSC (1998) LHHW and PSSA kinetic analysis of rates and adsorbate coverages in $\mathrm{CO} / \mathrm{H}_{2} /$ $\mathrm{C}_{2} \mathrm{H}_{4}$ reactions on $\mathrm{Mn}-\mathrm{Rh} / \mathrm{SiO}_{2}$. J Catal 173:122-133

39. Kusama H, Okabe K, Sayama K, Arakawa H (1996) $\mathrm{CO}_{2}$ hydrogenation to ethanol over promoted $\mathrm{Rh} / \mathrm{SiO}_{2}$ catalysts. Catal Today 28:261-266
40. Chuang SC, Goodwin JG, Wender I (1985) The effect of alkali promotion on $\mathrm{CO}$ hydrogenation over $\mathrm{RhTiO}_{2}$. J Catal 95:435-446

41. Tien-Thao N, Hassan Zahedi-Niaki M, Alamdari H, Kaliaguine $\mathrm{S}$ (2007) Effect of alkali additives over nanocrystalline $\mathrm{Co}-\mathrm{Cu}-$ based perovskites as catalysts for higher-alcohol synthesis. J Catal 245:348-357

42. Hakeem AA, Vásquez RS, Rajendran J, Li M, Berger RJ, Delgado JJ, Kapteijn F, Makkee M (2014) The role of rhodium in the mechanism of the water-gas shift over zirconia supported iron oxide. J Catal 313:34-45

43. Wong C, McCabe RW (1987) Effects of oxidation/reduction treatments on the morphology of silica-supported rhodium catalysts. J Catal 107:535-547

44. Lopez L, Velasco J, Montes V, Marinas A, Cabrera S, Boutonnet M, Järås S (2015) Synthesis of ethanol from syngas over Rh/ MCM-41 catalyst: effect of water on product selectivity. Catalysts $5: 1737$

45. Trautmann S, Baerns M (1994) Infrared spectroscopic studies of $\mathrm{CO}$ adsorption on rhodium supported by $\mathrm{SiO}_{2}, \mathrm{Al}_{2} \mathrm{O}_{3}$, and $\mathrm{TiO}_{2}$. J Catal 150:335-344

46. Fisher IA, Bell AT (1996) A comparative study of $\mathrm{CO}$ and $\mathrm{CO}_{2}$ hydrogenation over $\mathrm{Rh} / \mathrm{SiO}_{2}$. J Catal 162:54-65

47. Trevino H, Lei GD, Sachtler WMH (1995) CO hydrogenation to higher oxygenates over promoted rhodium: nature of the metalpromoter interaction in Rhmn/NaY. J Catal 154:245-252

48. Wang S-R, Guo W-W, Wang H-X, Zhu L-J, Qiu K-Z (2014) Influence of Mn promotion on CO hydrogenation over Rh/CNTs catalyst. Catal Lett 144:1305-1312

49. Choi Y, Liu P (2009) Mechanism of ethanol synthesis from syngas on Rh(111). J Am Chem Soc 131:13054-13061

50. Chuang SSC, Pien SI (1992) Infrared study of the CO insertion reaction on reduced, oxidized, and sulfided $\mathrm{Rh} / \mathrm{SiO}_{2}$ catalysts. J Catal 135:618-634

51. Hironori A, Kazuhiko T, Takehiko M, Yoshihiro S (1984) Effect of metal dispersion on the activity and selectivity of $\mathrm{Rh} / \mathrm{SiO}_{2}$ catalyst for high pressure CO hydrogenation. Chem Lett 13:1607-1610

52. Van Santen RA (2009) Complementary structure sensitive and insensitive catalytic relationships. Acc Chem Res 42:57-66

53. Wang Y, Luo H, Liang D, Bao X (2000) Different mechanisms for the formation of acetaldehyde and ethanol on the Rh-based catalysts. J Catal 196:46-55

54. Gronchi P, Tempesti E, Mazzocchia C (1994) Metal dispersion dependent selectivities for syngas conversion to ethanol on $\mathrm{V}_{2} \mathrm{O}_{3}$ supported rhodium. Appl Catal A 120:115-126

Publisher's Note Springer Nature remains neutral with regard to jurisdictional claims in published maps and institutional affiliations. 